\title{
Three-Dimensional Geologic Model of the Southeastern Española Basin, Santa Fe County, New Mexico
}

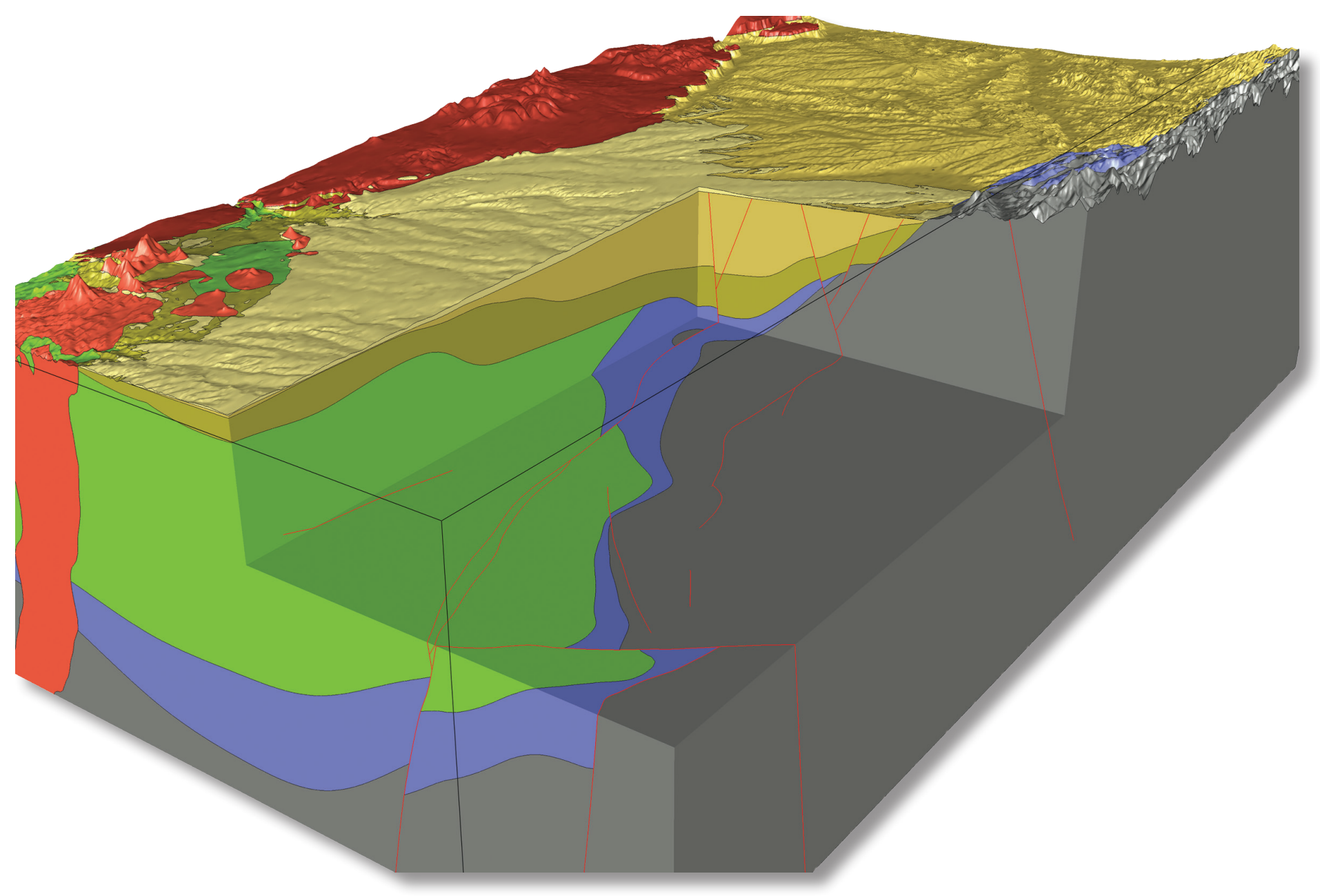

Scientific Investigations Report 2011-5025 


\section{Three-Dimensional Geologic Model of the Southeastern Española Basin, Santa Fe County, New Mexico}

By Michael P. Pantea, Mark R. Hudson, V.J.S. Grauch, and Scott A. Minor

Scientific Investigations Report 2011-5025 


\title{
U.S. Department of the Interior \\ KEN SALAZAR, Secretary \\ U.S. Geological Survey \\ Marcia K. McNutt, Director
}

\section{U.S. Geological Survey, Reston, Virginia: 2011}

\author{
For more information on the USGS — the Federal source for science about the Earth, its natural and living resources, \\ natural hazards, and the environment, visit http://www.usgs.gov or call 1-888-ASK-USGS \\ For an overview of USGS information products, including maps, imagery, and publications, \\ visit http://www.usgs.gov/pubprod \\ To order this and other USGS information products, visit http://store.usgs.gov
}

\begin{abstract}
Any use of trade, product, or firm names is for descriptive purposes only and does not imply endorsement by the U.S. Government.

Although this report is in the public domain, permission must be secured from the individual copyright owners to reproduce any copyrighted materials contained within this report.
\end{abstract}

Suggested citation:

Pantea, M.P., Hudson, M.R., Grauch, V.J.S., and Minor, S.A., 2011, Three-dimensional geologic model of the southeastern Española Basin, Santa Fe County, New Mexico: U.S. Geological Survey Scientific Investigations Report 2011-5025, $17 \mathrm{p}$. 


\section{Contents}

Abstract
Introduction.
Geologic Setting
Stratigraphy
Modeled Geologic Elements and Descriptions
Modeled Stratigraphy
Modeled Intrusions
Model Construction
Methodology
References Cited
DVD-R0M Contents

\section{Figures}

1. Index map of New Mexico showing location of model area and modeled

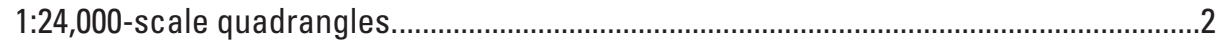

2. Index map showing location of Española Basin within the Rio Grande rift......................3

3. Generalized geology and geography of the study area ................................................

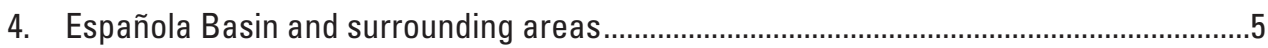

5. EarthVision ${ }^{\mathrm{TM}}$ image of geologic surfaces, faults, and fault systems used in model........7

6. EarthVision ${ }^{\mathrm{TM}}$ image of the geologic model showing bottom of Santa Fe Group, the Santa Fe embayment, the Rancho Viejo hinge zone, and deep structures in the model area. 


\title{
Three-Dimensional Geologic Model of the Southeastern Española Basin, Santa Fe County, New Mexico
}

\author{
By Michael P. Pantea, Mark R. Hudson, V.J.S. Grauch, and Scott A. Minor
}

\section{Abstract}

This multimedia model and report show and describe digital three-dimensional faulted surfaces and volumes of lithologic units that confine and constrain the basin-fill aquifers within the Española Basin of north-central New Mexico. These aquifers are the primary groundwater resource for the cities of Santa Fe and Española, six Pueblo nations, and the surrounding areas. The model presented in this report is a synthesis of geologic information that includes (1) aeromagnetic and gravity data and seismic cross sections; (2) lithologic descriptions, interpretations, and geophysical logs from selected drill holes; (3) geologic maps, geologic cross sections, and interpretations; and (4) mapped faults and interpreted faults from geophysical data. Modeled faults individually or collectively affect the continuity of the rocks that contain the basin aquifers; they also help define the form of this rift basin. Structure, trend, and dip data not previously published were added; these structures are derived from interpretations of geophysical information and recent field observations. Where possible, data were compared and validated and reflect the complex relations of structures in this part of the Rio Grande rift.

This interactive geologic framework model can be used as a tool to visually explore and study geologic structures within the Española Basin, to show the connectivity of geologic units of high and low permeability between and across faults, and to show approximate dips of the lithologic units. The viewing software can be used to display other data and information, such as drill-hole data, within this geologic framework model in three-dimensional space.

\section{Introduction}

Aquifers within the Española Basin are the primary water resource for Santa Fe County, New Mexico, including the city of Santa Fe and surrounding cities and pueblos. Longworth and others (2008) show that in 2005, 73 percent of all nonagricultural and 59 percent of total water use in Santa Fe County was from groundwater withdrawals. Thus, understanding the geologic framework in three dimensions and its controls on groundwater flow are vital to understanding and managing these resources.

The three-dimensional (3-D) model in this report integrates lithologic layers and structural features that constrain the groundwater aquifers within the modeled Española Basin area in north-central New Mexico (fig. 1). The modeled area is composed of all or parts of nine 7.5-minute quadrangles: Agua Fria, Galisteo, Horcado Ranch, Picture Rock, Santa Fe, Seton Village, Tesuque, Turquoise Hill, and White Rock (fig. 1). The model shows faulted geologic surfaces constructed using data from mapped geologic contacts, faults, and other geologic structures, and interpreted aeromagnetic and gravity data.

This study integrates numerous geoscience data types, such as geophysical data with surface geologic maps, to show the 3-D configuration of geologic units and structures of the basin-fill aquifers within the Española Basin. Integrating different geoscience data sets made the model internally consistent and more accurate because of the cross-validation of the different data types.

The model iteratively progressed from simple to complex using Dynamic Graphics EarthVision ${ }^{\mathrm{TM}}$ (EV) software to be used as a visual interactive tool for nontechnical and technical audiences. Viewing the data and model in 3-D space makes it easier to evaluate the shape and form of the stratigraphic units that compose the aquifers within the study area. The model shows geologic characteristics that may affect or control groundwater within this part of the Española Basin, including (1) the complex relations between fault-bounded lithologic units, (2) possible flow pathways or barriers along or across fault boundaries, (3) possible flow pathways within tilted fault-bounded lithologic units, and (4) the subsurface configuration of porous sediments overlying fracture-dominated basement and volcanic rocks. 


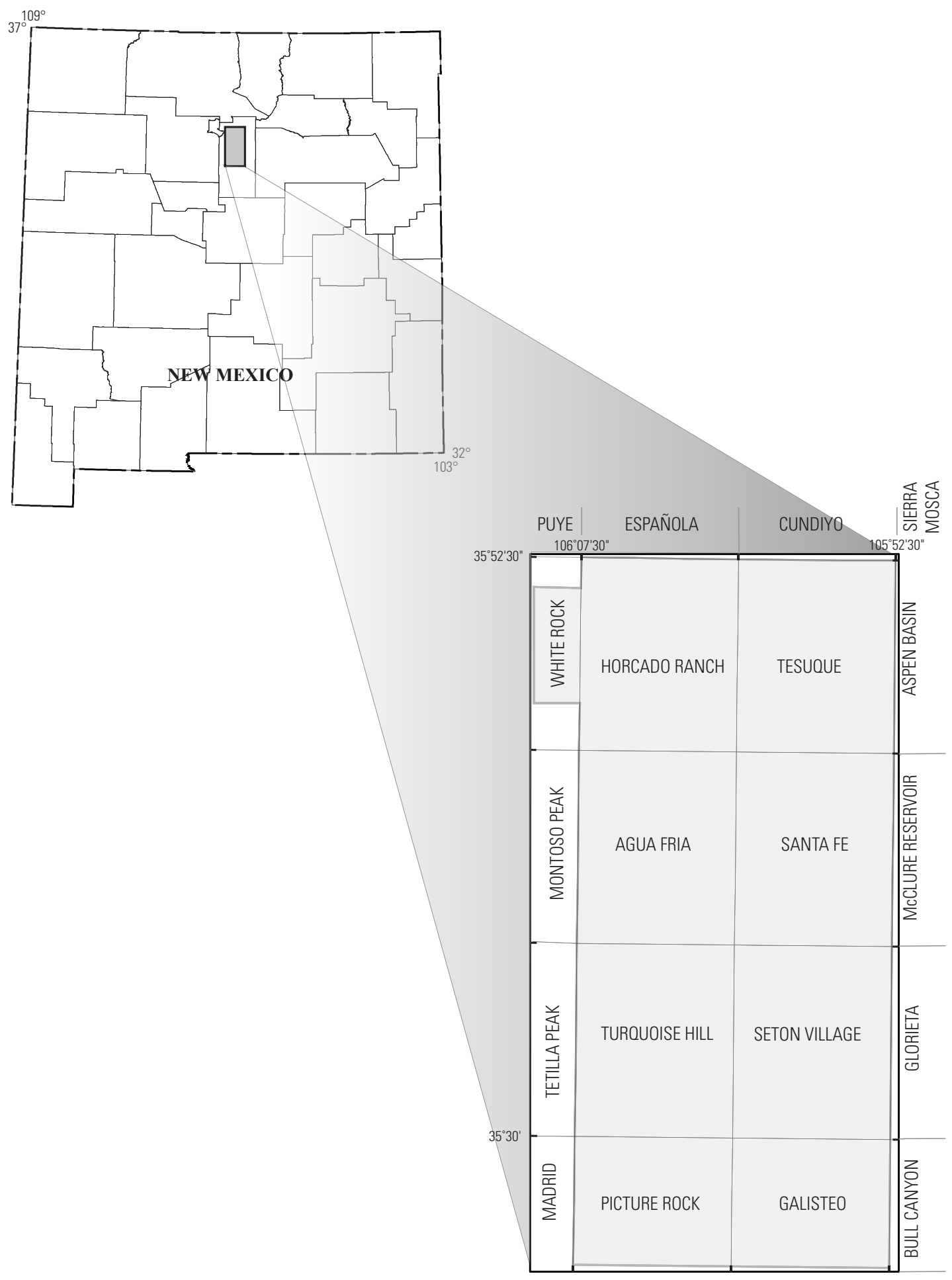

Figure 1. Index map of New Mexico showing location of model area and modeled 1:24,000-scale quadrangles. 


\section{Geologic Setting}

\section{Stratigraphy}

The 550-km-long Rio Grande rift is composed of a series of linked sedimentary basins trending northward from southern New Mexico into southern Colorado. The focus of this report is the Española Basin, which is one in a series of four structurally linked, north-trending, right-stepping, en echelon basins in the central part of the rift (fig. 2). From south to north these basins are Albuquerque, Santo Domingo, Española, and San Luis Basins. These basins mostly developed and subsided during the Miocene and Pliocene (Neogene) and are filled with poorly lithified siliciclastic sediments and a variety of intrusive and extrusive igneous rocks (Kelley, 1979, 1982; Chapin and Cather, 1994).

The Española Basin contains Proterozoic crystalline basement rocks, exposed in the Santa $\mathrm{Fe}$ and Sangre de Cristo Mountains (figs. 3 and 4), which are unconformably overlain by upper Paleozoic and Mesozoic sedimentary rocks. The Proterozoic to Mesozoic rocks have undergone various degrees of Laramide contractional and transpressional deformation along mainly north- and northeast-trending faults and folds
(Kelley, 1979). These trends are thought to be inherited from 1.65-0.8 Ga structural discontinuities and anisotropies present within the Proterozoic rocks (Karlstrom and Humphreys, 1998; Karlstrom and others, 1999; Cather and others, 2005). Syn- and post-Laramide Eocene sedimentary and Eocene and Oligocene volcanic and volcaniclastic rocks unconformably overlie these older rocks and are locally preserved along the western basin margins.

The Española Basin is mostly filled with eolian, fluvial, and alluvial sediments of the Santa Fe Group that were deposited during the Miocene, Pliocene, and early Pleistocene when rift-related basin subsidence was at its peak (Connell and others, 1999; Smith and others, 2001; Dethier and Sawyer, 2006; Connell, 2006; Williams and Cole, 2007). Overall, the basin sediments become less indurated and coarsen up-section due to a basin drainage system that evolved from closed to integrated (Dethier and Sawyer, 2006). Most lateral facies changes exist in part due to the effects of syndepositional growth faulting that accompanied rifting (for example, May and Russell, 1994; Connell and others, 1999; Smith and others, 2001; Minor, 2006). Composite thickness of the Santa Fe Group is greater than $10,000 \mathrm{ft}$ within the basin (Grauch and others, 2009).

Three main episodes of volcanism occurred in and adjacent to the Española Basin during the development of the Rio

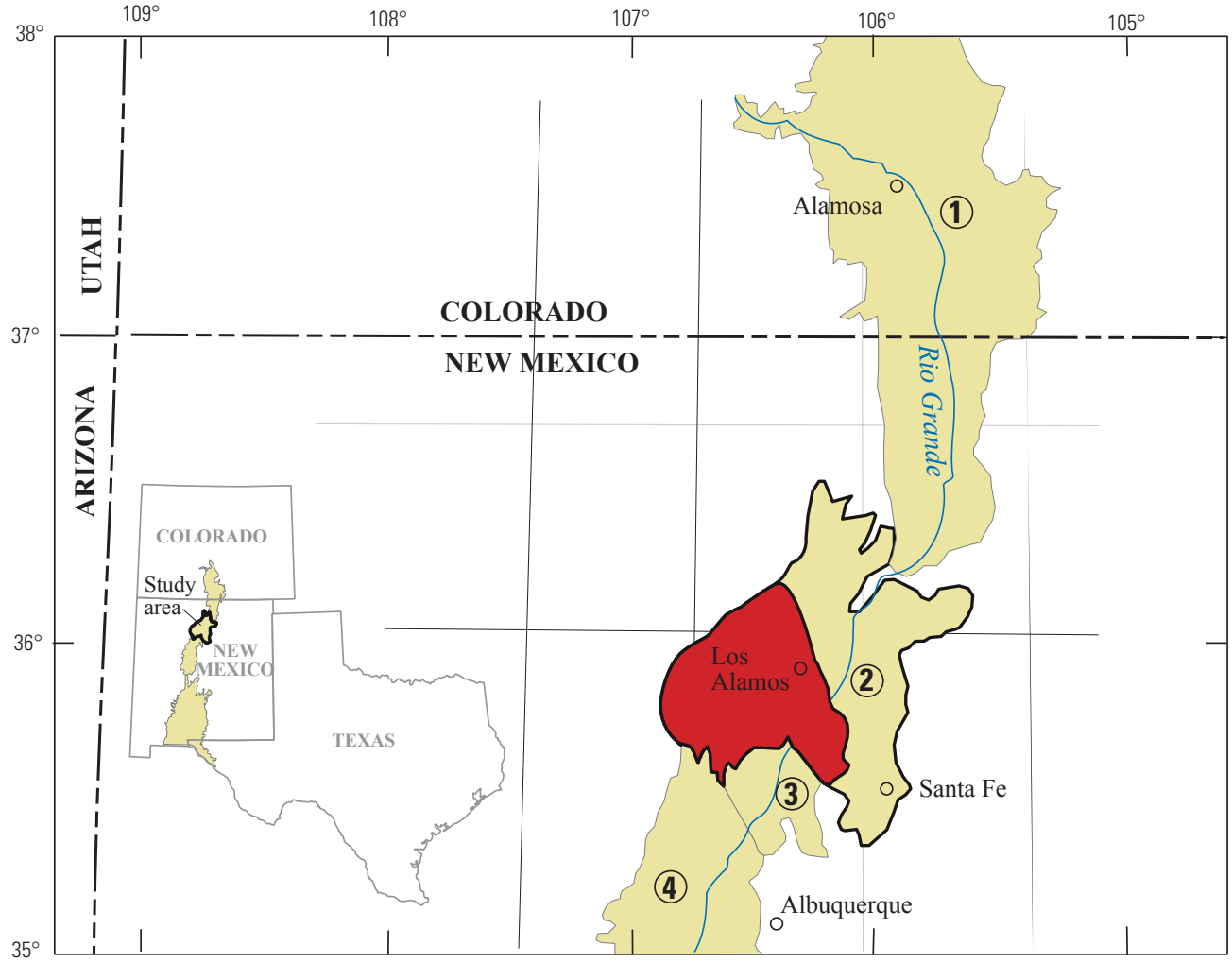

EXPLANATION

Area of basin fill

(1) San Luis Basin

(2) Española Basin

(3) Santo Domingo Basin

(4) Albuquerque Basin

Volcanic field

Figure 2. Index map showing location of Española Basin within the Rio Grande rift. 


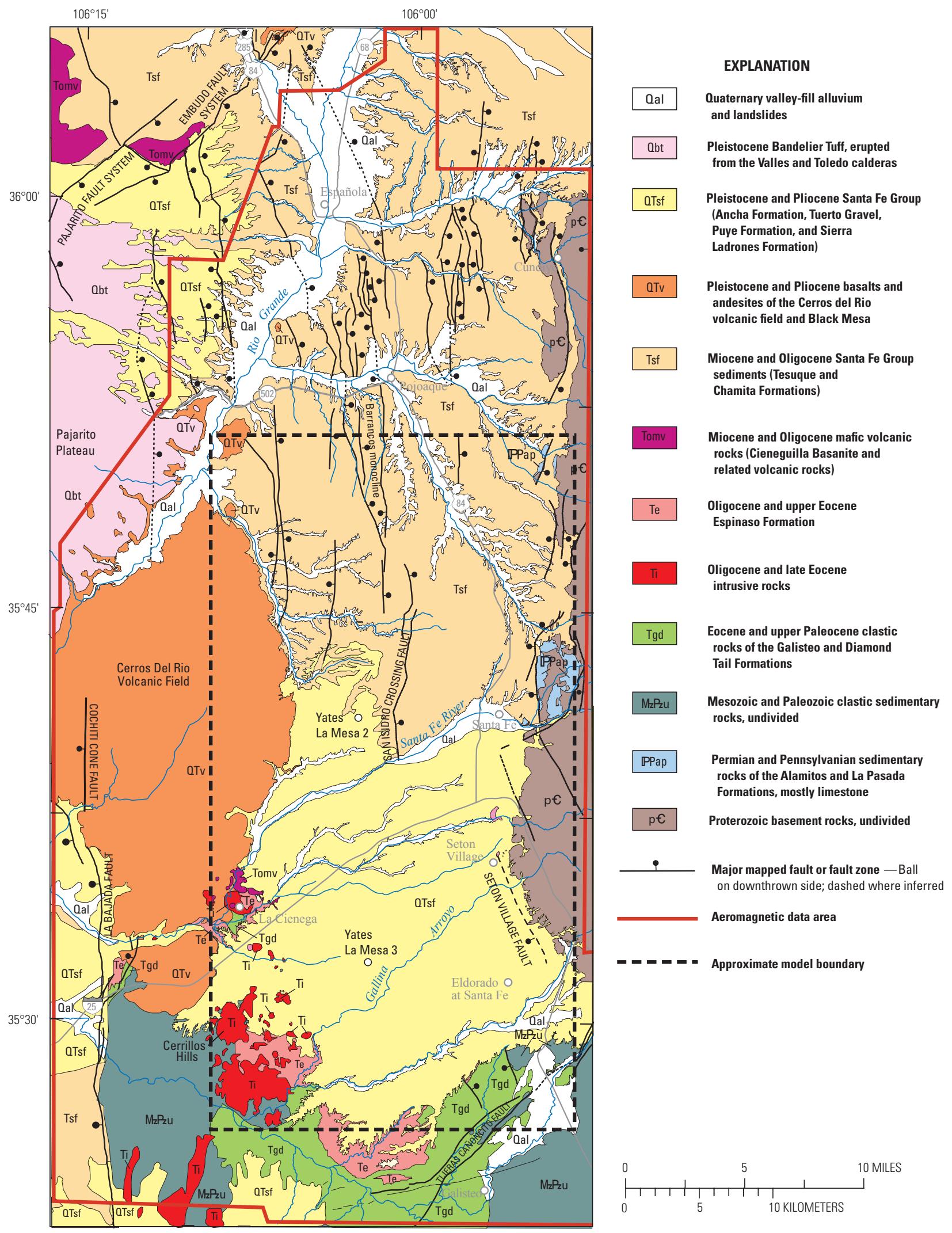

Figure 3. Generalized geology and geography of the study area. Geologic contacts are generalized from Read and others (2005), Minor (2006), New Mexico Bureau of Geology and Mineral Resources, (2003), Koning (2005), and Koning and others (2005). 


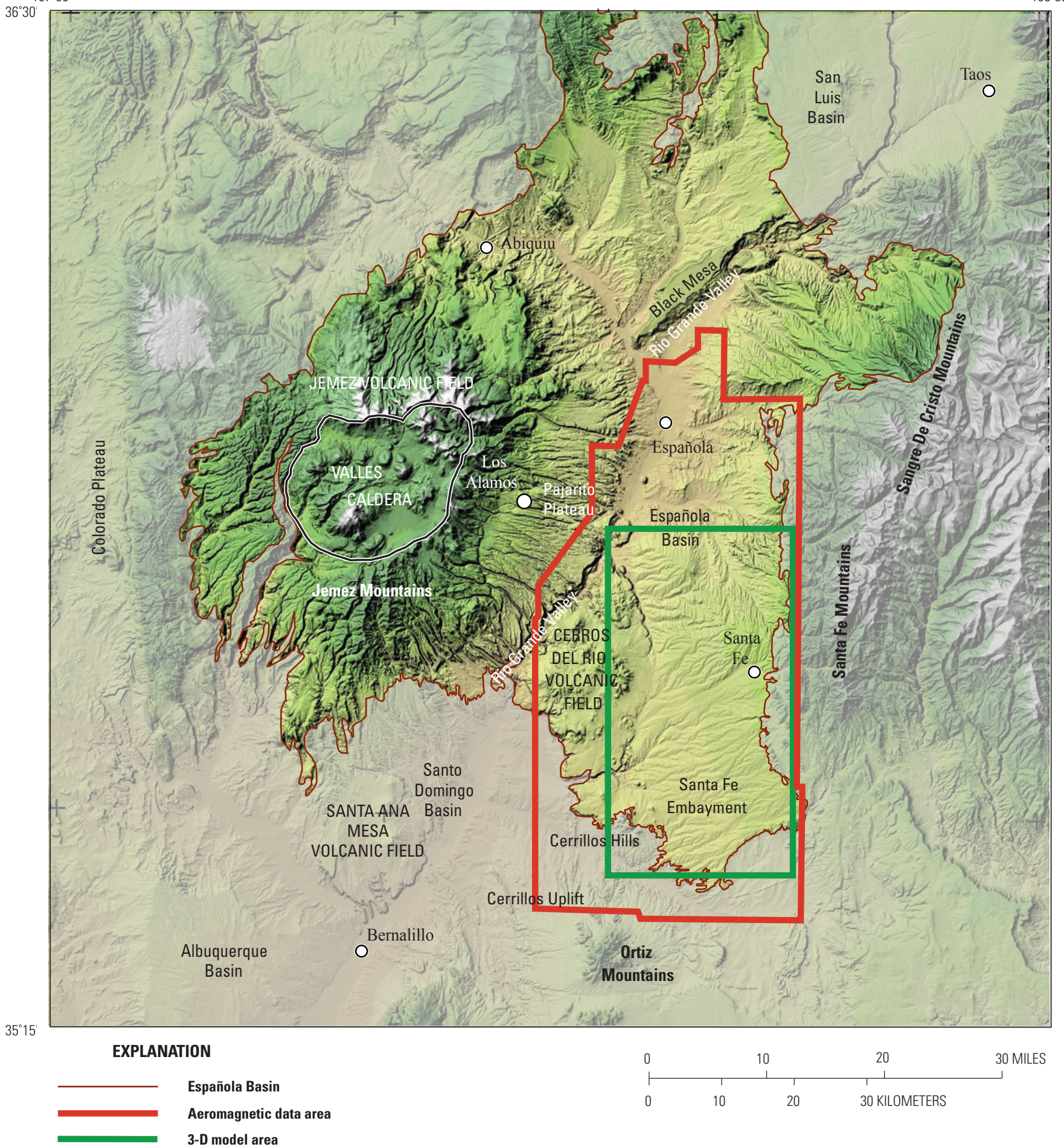

Figure 4. Española Basin and surrounding areas. Processed Landsat satellite imagery is from Sawyer and others (2004). Overall topographic relief within the study area is $1,145 \mathrm{~m}(3,750 \mathrm{ft})$. 
Grande rift, beginning with the Miocene (12-6.5 Ma) eruptions in the Jemez volcanic field that overlaps the northwest side of the rift (Smith and others, 1970) in the area of the Pajarito Plateau (fig. 4). Silicic and intermediate lavas, pyroclastic deposits, and volcaniclastic sediments originating from the Jemez volcanic field are intercalated with basin-fill sediments within the western Española Basin area. A second, late Pliocene to early Pleistocene (2.7-1.1 Ma) episode of localized basalt and andesite lava eruptions was restricted to the center of the Santo Domingo Basin (Santa Ana Mesa volcanic field) and the Cerrillos del Rio volcanic field between the Santo Domingo and Española Basins (fig. 4) (Thompson and others, 2006). A third, distinct volcanic episode occurred in the Jemez volcanic field west of the Española Basin consisting of two voluminous silicic eruptions of the Bandelier Tuff at 1.6 and 1.2 Ma, with concomitant collapse of the Valles caldera (fig. 4) (Smith and Bailey, 1968; Smith and others, 1970).

\section{Structure}

The Rio Grande rift consists of a series of basins, of which most are broadly asymmetrical half grabens (Rosendahl, 1987), and intrabasin strata and north- to south-striking normal faults have opposing east-west dips (Chapin and Cather, 1994; Russell and Snelson, 1994). Both the Albuquerque and Española Basins exhibit crude half-graben structural geometries; dips of the primary fault structures of the Albuquerque Basin are mostly to the west, whereas in the Española Basin dips are mostly to the east (Kelley, 1982; Chapin and Cather, 1994). The Santo Domingo Basin, located between the Albuquerque and Española Basins, has a more symmetrical structural form and shares structural affinities with both of the adjoining basins.

Faults in the interior of the Española Basin and model area mostly strike north to north-northwest and dip both to the east and to the west (figs. 5 and 6). The southern, narrow part of the Española Basin, known as the Santa Fe embayment (figs. 4 and 6), is underlain by a broad apron of Pliocene and Pleistocene $(<3 \mathrm{Ma})$ basin alluvial deposits that overlap a shallow platform of Oligocene and older rocks. The platform is separated from the main, much deeper part of the basin to the north by the Rancho Viejo "hinge zone" (fig. 6). This zone is a buried, sinuous, geophysically well-expressed, northerly dipping monoclinal ramp that may have formed in the latest Oligocene during extensional development of the Española Basin (Grauch and others, 2009). North of the Rancho Viejo hinge zone, most of the pre-rift Paleozoic to Eocene sedimentary section was removed by erosion, before Santa Fe Group deposition began. As the basin subsided during rifting, this erosional surface was structurally deepened and unconformably overlain by Santa Fe Group sediments. The pre-rift sedimentary section is better preserved south of the hinge zone and crops out in the southern part of the model area. Although no faults cut the shallow Pliocene and Pleistocene deposits in the Santa Fe embayment, several large, geophysically traced, north- to northwest-striking normal faults displace the underlying older rocks (Aqua Fria fault system, fig. 5). At the south end of the embayment, these faults terminate against an extensive, discrete zone of northeast-striking faults- the Tijeras-Cañoncito fault (fig. 5). This fault zone has had a long and complex kinematic history, including strike-slip and dipslip movement on some segments (Lisenbee and others, 1979; Abbott and others, 2004).

The master, down-to-the-east, border fault of the Española Basin is the large-displacement (300-1,000 m maximum) Pajarito fault system, northwest of the modeled area (fig. 3). The footwall of the system forms the eastern edge of the Jemez Mountains and has probably been active during most of the Española Basin's rift history (Gardner and Goff, 1984; Sawyer and Minor, 2006a). North of Los Alamos, the rightstepping Pajarito fault system curves into a northeast trend and merges with the Embudo fault system (fig. 3). The Embudo fault system is a discrete zone of closely spaced, northeaststriking faults that continues northeast toward Taos, N. Mex., where it merges with the down-to-the-west master border fault of the San Luis Basin. The Embudo system probably experienced large components of left-lateral strike slip since about $7 \mathrm{Ma}$ (Koning and others, 2004), and this movement has continued into the Quaternary (Koning and others, 2004; Kelson and others, 2004). Recent workers believe that the Embudo fault system is a strike-slip transfer zone that relayed extensional strain between the opposite-polarity Española and San Luis half-graben basins during the main period of rifting (Kelley, 1982; Aldrich, 1986; Chapin and Cather, 1994; Faulds and Varga, 1998; Koning and others, 2004; Kelson and others, 2004).

\section{Modeled Geologic Elements and Descriptions}

The 3-D geologic model consists of surfaces that mostly represent unconformities below major stratigraphic units, boundaries that characterize the lateral extents of intrusions, and faults that intersect geologic surfaces. The top of the model is defined by the U.S. Geological Survey (USGS) ten-meter digital elevation model (DEM) topography. The geologic elements were selected for modeling because of their probable hydrologic significance and their ease of identification from surface geologic mapping or from subsurface geophysical analysis and drill-hole information. Each geologic element, its hydrogeologic significance, and sources of information for its construction in the 3-D model are described in the following sections.

\section{Modeled Stratigraphy}

The generalized stratigraphic units represented in the 3-D model include, from youngest to oldest, basalts and cinder cones of the Cerros del Rio volcanic field, the Ancha and 


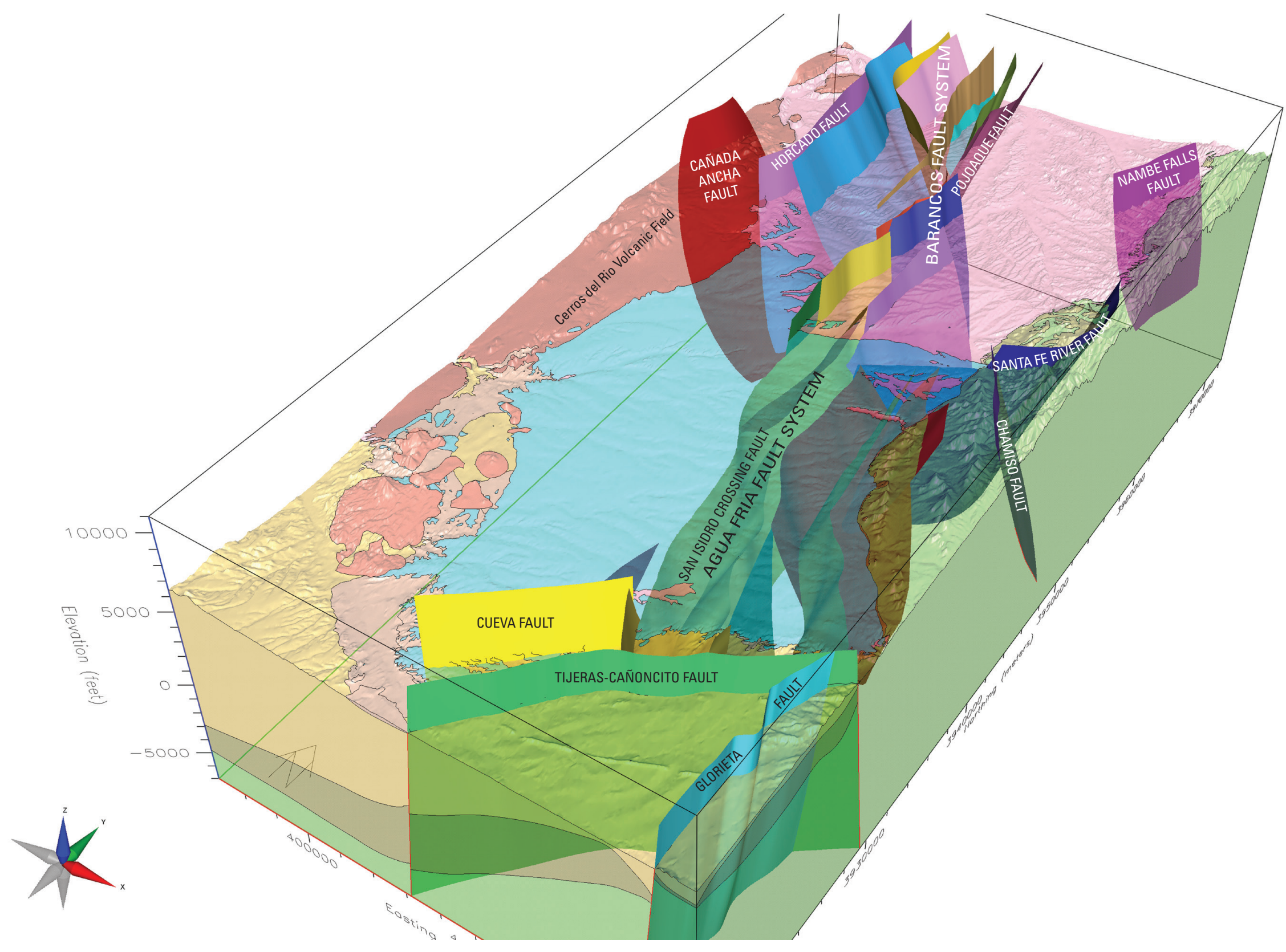

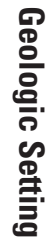

Figure 5. EarthVision ${ }^{\mathrm{TM}}$ image of geologic surfaces, faults, and fault systems used in model. Named structures are referenced in this report. 


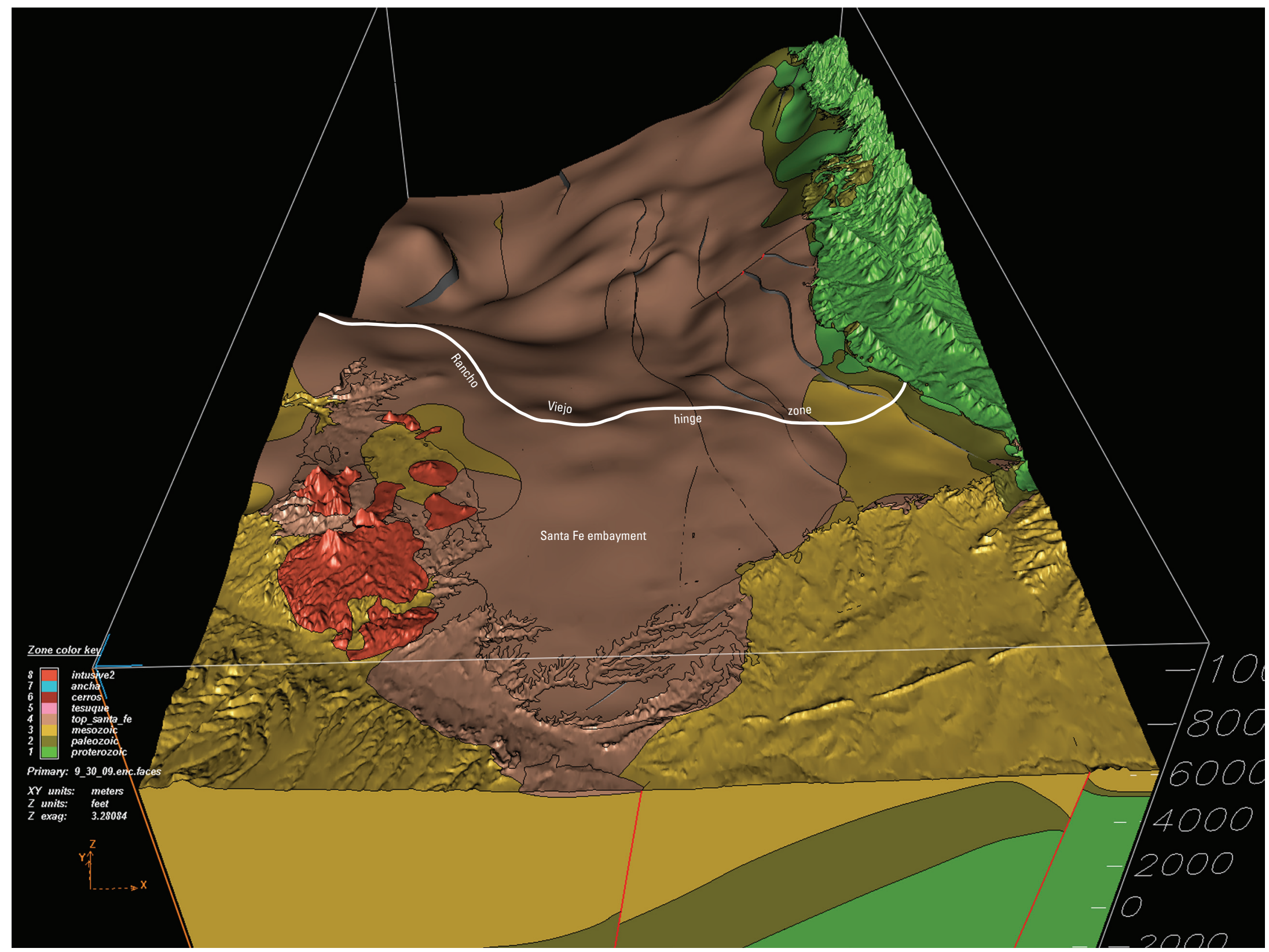

Figure 6. EarthVision ${ }^{\mathrm{TM}}$ image of the geologic model showing bottom of Santa Fe Group, the Santa Fe embayment, the Rancho Viejo hinge zone, and deep structures in the model area. 
Tesuque Formations of the Santa Fe Group, Oligocene volcanic and volcaniclastic rocks, Oligocene igneous intrusives, undifferentiated Eocene to Paleozoic sedimentary (primarily clastic) rocks, the basal Paleozoic sedimentary section (dominantly limestone), and Proterozoic crystalline basement. In this report the base of the Santa Fe Group is defined as the floor of the Española Basin. Also, both the Santa Fe Group and the Cerros del Rio volcanic rocks are considered basin fill. Unit names in closed parenthesis are the unit names keyed to the model. Stratigraphic sequence shown in model is not time correlated but is based on how the model needed to be constructed.

Pleistocene-Pliocene Cerros del Rio volcanic field (Cerros_Del_Rio) - The Cerros del Rio volcanic field (fig. 3) is a predominantly basaltic to andesitic volcanic plateau that generally overlies the Tesuque Formation (Thompson and others, 2006). About $120 \mathrm{~km}^{3}$ of rift-related mafic magma was erupted discontinuously from 2.7 to $1.1 \mathrm{Ma}$ as lavas and related pyroclastic deposits, with the thickness and extent of individual eruptive products generally varying according to composition (Thompson and others, 2006). Overall thickness of the volcanic pile ranges from a few meters along the eastern margin of the field to as much as $250 \mathrm{~m}$ in the central part, as observed in wells and interpreted from electromagnetic data (Thompson and others, 2006; Rodriguez and others, 2006).

Basalts of the Cerros del Rio are generally above the water table (Sawyer and Minor, 2006b). However, the basalts are important because they cap the potentially large thickness $(\approx 1 \mathrm{~km})$ of aquifer-forming sediments of the Santa Fe Group (Grauch and others, 2006, 2009), which may transmit groundwater underneath the volcanic field. Information on the extent and thickness of the Cerros del Rio volcanic field was determined from mapped geologic contacts (Read and others, 2005) and limited drill-hole information (Sawyer and Minor, 2006b).

Pleistocene and Pliocene Ancha Formation (Ancha) The Ancha Formation represents the uppermost part of the Santa Fe Group, typically less than $90 \mathrm{~m}$ (300 ft) thick. It is restricted to the southern part of the model area (fig. 3) and consists of poorly consolidated sand, gravel, and clayey-silty sand that were shed from the Santa Fe Range from east to west (Koning and others, 2002; Koning and Johnson, 2005). It is relatively undeformed and unconformably overlies the Tesuque Formation and older rocks.

The Ancha Formation is a high-permeability aquifer where it is saturated, but it is mostly unsaturated throughout the model area (Lewis and West, 1995; Johnson and others, 2008). The modeled base of the Ancha Formation was determined from mapped geologic contacts (Read and others, 2005) and from a grid derived from picks determined from cuttings and driller's logs for numerous shallow wells in the southern part of the model area (Johnson and others, 2008).

Miocene Tesuque Formation (Tesuque) - The Tesuque Formation, part of the Santa Fe Group, represents the bulk of basin fill north of the Rancho Viejo hinge zone (figs. 6). Although the upper part of the Tesuque Formation is timeequivalent to and interfingers with the basin-fill Chamita
Formation (fig. 3) near the northeastern corner of the model area (Koning and Aby, 2005), we do not separate these two units in the model. The Tesuque Formation is composed primarily of sandstone and silty-clayey sandstone with minor conglomerate, siltstone, and claystone (Spiegel and Baldwin, 1963; Borchert and others, 2003; Koning and Maldonado, 2003; Koning and Read, 2010). The formation has been previously subdivided into lithostratigraphic units (not modeled here) on the basis of differences in sediment source areas and depositional environments that evolved during the development of the Española Basin (Cavazza, 1986; Koning and Johnson, 2006; Koning and others, 2008). Coarse-grained sediments dominate the upper part of the section throughout the model area. Grain sizes are more variable in the lower part of the section, with finer grained sediments concentrated under what is now the Rio Grande Valley (fig. 4) (Koning and others, 2008). The Tesuque Formation was deposited on an erosional surface that may have had considerable relief, as much as 150 $\mathrm{m}$ in the Santa Fe embayment (figs. 4 and 6), then was tilted and faulted prior to deposition of the Ancha Formation in early Pliocene time (Koning and Johnson, 2005; Grauch and others, 2009). Stratal tilts of the Tesuque Formation generally mimic the tilts of the basin floor, with steeper dips along the eastern mountain front (Koning and Read, 2010).

The Tesuque Formation forms the primary aquifer for groundwater resources in the southeastern Española Basin. The base of the Tesuque Formation was determined from mapped geologic contacts (Read and others, 2005) and from a digital grid developed as part of an integrated, 3-D geophysical model (Grauch and others, 2009). The geophysically derived grid was constructed through synthesis of gravity and aeromagnetic analyses and models, drill-hole information, seismic-reflection and electromagnetic constraints, and geologic mapping and interpretations (Grauch and others 2009).

Oligocene and Eocene volcanic and volcaniclastic rocks (older_volcanic) - The Espinaso Formation and the overlying Cieneguilla Basinite and related volcanic rocks are modeled as one unit (fig. 3). The Espinaso Formation is composed of volcaniclastic sandstones, conglomerates, boulder conglomerates, near-vent volcaniclastic breccias, and minor intermediate-composition lava flows (Kautz and others, 1981; Smith and others, 1991; Thompson and others, 2006). Kautz and others (1981) and Erskine and Smith (1993) interpret the Espinaso Formation as an extensive apron of volcaniclastic debris as much as $400 \mathrm{~m}$ thick that accumulated next to Oligocene volcanic centers associated with intrusions near the Cerrillos Hills (described below) and to the south. The overlying Cieneguilla Basinite and related volcanic rocks are composed of basanite and nephelenite lava flows and interbedded sediments, as much as $200 \mathrm{~m}$ (660 ft) thick (Sawyer and others, 2002; Thompson and others, 2006).

This rock package is an important element of the hydrogeologic framework because (1) the rocks directly underlie Santa Fe Group sediments in most of the southern part of the study area; (2) they generally form the lower confining unit (Spiegel and Baldwin, 1963), although permeabilities 
may be moderate in local areas; (3) their absence indicates areas where the overlying Santa Fe Group and underlying pre-rift section have hydraulic connection; and (4) they likely contribute locally to poor groundwater quality. The base of the Oligocene volcanic and volcaniclastic rock package was determined from mapped geologic contacts (Read and others, 2005) and a digital grid developed as part of an integrated, 3-D geophysical model (Grauch and others, 2009). The geophysically derived grid was constructed primarily from aeromagnetic analyses, drill-hole information, and seismic-reflection constraints (Grauch and others 2009).

Eocene to upper Paleozoic clastic sedimentary rocks (Eoc_uPaleo_clastic)-Undifferentiated, dominantly clastic sedimentary rocks younger than Pennsylvanian and older than Oligocene are modeled as one unit (fig. 3). This section is poorly known in the model area because it has been variably reduced by erosion (Koning and Read, 2010). It is entirely missing above the basal, limestone-dominated Pennsylvanian sequence in Yates La Mesa \#2 well (fig. 3) (Myer and Smith, 2006). Because of this uncertainty, it is defined in the subsurface as the interval between the base of the Oligocene volcanic and volcaniclastic rock package and the top of the limestonedominated Pennsylvanian rocks. The fully preserved section may include as much as $2,000 \mathrm{~m}(6,560 \mathrm{ft})$ of Permian through Cretaceous sandstones, siltstones, shales, minor conglomerates, and limestones. Unconformably overlying the Paleozoic and Mesozoic section are Paleocene and Eocene sandstones and siltstones that were deposited during the late stages of the Laramide orogeny (Cather, 1992, 2004; Lucas and others, 1997). At the top of the section, the Eocene Galisteo Formation may be important locally for water storage in the southern part of the model area (Finch, 2008), and may be as much as $1,500 \mathrm{~m}(4,920 \mathrm{ft})$ thick (Abbott and others, 1995).

Paleozoic carbonate-dominated sedimentary rocks (Pz_carb) - Pennsylvanian and minor Mississippian rocks composed of limestone and lesser amounts of calcareous siltstone, shale, and sandstone form the base of the Phanerozoic section in the model area (fig. 3) (Spiegel and Baldwin, 1963). This section is the only part of the Paleozoic section preserved above the Proterozoic basement throughout much of the northern half of the model area. This interval is as much as $150 \mathrm{~m}(492 \mathrm{ft}$ ) thick in isolated exposures near the mountain front (Spiegel and Baldwin, 1963; Read and others, 2005; Koning and Read, 2010) and $400 \mathrm{~m}(1,312 \mathrm{ft})$ thick in the Yates La Mesa \#2 well (Myer and Smith, 2006). The limestone sequence produces prominent reflectors in seismic-reflection data, which are important markers for geophysical interpretation. They have similar densities to the Precambrian rocks, so they cannot be distinguished on the basis of gravity data (Grauch and others, 2009).

The limestones locally contain water in small vugs and caverns that formed from karst dissolution (Spiegel and Baldwin, 1963). These limestones are important near the mountain front along the eastern margin of the model area where the rocks have been uplifted and are closer to the surface. Information for the top of the Paleozoic limestone sequence was derived from geologic map contacts (Read and others, 2005) and was generally guided by geophysical interpretations and geologic cross sections that incorporated sparse drill-hole and seismic-reflection information (Read and others, 2005; Grauch and others, 2009; Koning and Read, 2010).

Proterozoic crystalline rocks (Proterozoic) - Proterozoic crystalline rocks are exposed along the eastern margin of the study area in the Santa Fe and Sangre de Cristo Mountains and form the geologic basement across the model area (fig. 3). They are predominantly granitic rocks with subordinate schist, gneiss, and amphibolite, and are highly brecciated in local areas (Spiegel and Baldwin, 1963; Read and others, 2003, 2004).

Proterozoic rocks are important for understanding the hydrogeologic framework because (1) the basement closely underlies and thus helps define the base of the rocks composing the basin-fill aquifers throughout most of the area north of the Santa Fe River; and (2) they form the main mountainblock aquifer, dominated by flow through fractures at depth. Information for the top of the Proterozoic basement surface was derived from geologic map contacts (Read and others, 2005), and a digital grid that was developed as part of an integrated 3-D geophysical model (Grauch and others, 2009). The geophysically derived grid was constructed primarily from aeromagnetic analyses and combined gravity and magnetic modeling that were constrained by limited drill-hole information and electromagnetic and seismic-reflection interpretations (Grauch and others 2009).

\section{Modeled Intrusions}

Oligocene and late Eocene intrusive rocks (intrusions) - A large intrusive complex and related plutons are located in the vicinity of the Cerrillos Hills (fig. 4), in the southwestern part of the modeled area. The intrusive rocks, composed of monzonite and monzonite porphyry, represent the roots of Oligocene volcanoes that erupted over several episodes (fig. 3) (Giles, 1995; Maynard and others, 2002). As the magma intruded, it domed the overlying sedimentary rocks (Maynard and others, 2002). The volcanoes were eventually eroded to form detritus of the Espinaso Formation (Kautz and others, 1981; Erskine and Smith, 1993).

The intrusions are important in the hydrogeologic framework because they likely represent a fracture-dominated rather than a porous medium. The lateral extents of the intrusions were determined from mapped geologic contacts (Read and others, 2005) and aeromagnetic interpretations (Grauch and others, 2009). At depth, the shapes of the intrusions are poorly constrained, so they are highly conceptualized.

\section{Modeled Structure}

Faults modeled were interpreted to impact the rift-basin structural form or to potentially affect groundwater flow by either bounding aquifers or by their intrinsic hydraulic 
properties (Caine and Minor, 2009). Faults were defined by surface geologic mapping as summarized by Read and others (2005) and Koning and Read (2010), augmented by new fault observations (S.A. Minor, M.R. Hudson, and R.A. Thompson, unpublished data, 2010) and fault signatures in geophysical data (Grauch and Hudson, 2007; Grauch and others, 2009).

The overall fault structure of the model consists of two main fault trends (fig. 5). (1) A northeast-striking set of faults that includes the Tijeras-Cañoncito fault in the southeastern corner of the model - a regional fault system with both Laramide and Neogene activity (Lisenbee and others, 1979; Abbott and others, 2004). The Tijeras-Cañoncito fault system is modeled as a primary fault because it crosses the model and is not offset by other faults in the model area. North of and parallel to the Tijeras-Cañoncito fault system is the northeaststriking Cueva fault that dips about $60^{\circ}$ southeast and is truncated at depth by the Tijeras-Cañoncito. (2) Most faults within the model lie within a north- to northwest-trending band that transects the model area. This band is further divided into two fault systems that cut strata of the Tesuque Formation - a southern Agua Fria system (Grauch and others, 2009) and a northern Barrancos system. The Agua Fria fault system contains the principal east-dipping San Isidro Crossing fault and extends from the Tijeras-Cañoncito fault in the south to north of the Santa Fe River arroyo where it is exposed and dips approximately $70^{\circ}$. The southern part of the Aqua Fria fault system does not cut the younger Ancha Formation and is interpreted from geophysical data. To the east, a group of west-dipping faults with shorter trace lengths are interpreted to be truncated at depth by the San Isidro Crossing fault. The Barrancos fault system steps to the west relative to the Agua Fria fault system (fig. 5). The mostly east-dipping Barrancos system coincides with an area of west-dipping strata, and the overall structural geometry is interpreted to be a faulted down-to-the-west monocline (Barrancos monocline, figs. 3 and 5). The adjacent Pojoaque fault dips approximately $75^{\circ}$ west and is interpreted as the main causative fault of the monocline against which other mostly east-dipping faults of the Barrancos system truncate (fig. 5).

In addition to the two main fault trends, other peripheral faults are included in the model (fig. 5). West of the Barrancos fault system, the east-dipping Horcado and Cañada Ancha faults follow the western flank of a geophysically defined structural trough (Grauch and others, 2009). The form of the trough guided modeling of fault offsets and the general location of the Cañada Ancha fault, which is buried by the Cerros del Rio volcanic field. Offset on the Horcado fault is principally constrained by gravity inversion. The general structure of the Santa Fe Mountains on the eastern side of the basin is an west-dipping monocline broken by several subordinate faults. The Santa Fe River fault projects southwestward into the basin from exposures within Proterozoic rocks in the canyon where its namesake river flows out of the mountains (figs. 3 and 5). Other north-striking faults within the eastern part of the basin are interpreted to truncate against this fault. Farther north along the mountain front, the east-dipping Nambe Falls fault (fig. 5) juxtaposes older Paleozoic and Proterozoic rocks on the west against the Tesuque Formation. At the southeastern corner of the model, the steeply west-dipping, curviplanar Glorieta fault projects northward to the Tijeras-Cañoncito fault, and at the surface juxtaposes Triassic sedimentary rock on the east against Cretaceous through Eocene rocks (fig. 5).

\section{Model Construction and Methodology}

\section{Model Construction}

EarthVision $^{\mathrm{TM}}(\mathrm{EV})$ software was used to create, compile, and display the model because of its ability to interactively use and view different data types. In addition, it can accurately define and show faulted geologic surfaces while maintaining structural complexity and integrity in three dimensions. The software creates three-dimensional mathematically defined surfaces from $\mathrm{x}, \mathrm{y}$, and $\mathrm{z}$ data points. For this model $\mathrm{x}$ and $\mathrm{y}$ are a Universal Transverse Mercator (UTM), NAD 27, zone 13 , location in meters, and $\mathrm{z}$ is elevation in feet. Modeled surfaces were derived using the native "minimum surfacetension" gridding algorithm to more closely model the data. The gridded lithologic surfaces are generated in a two-stage process, an initial grid estimate followed by biharmonic iterations. Initial grid nodes are estimated from the scattered data. Data points used for the initial estimate depend on the distribution of the scattered data. Once the estimate is complete, a number of iterations using the biharmonic cubic-spline function re-evaluate the grid nodes. So that grid nodes still adhere to the scattered data, a scattered data feedback algorithm follows each biharmonic iteration. These modeling steps result in the curvature of the surface being distributed between data points rather than concentrated at data points. This generates a more natural looking modeled surface of the grid nodes that accurately reflect the scattered data. More information and other utilities are available from Dynamic Graphics, Inc., at URL http: //www.dgi.com.

Volumes of units are defined and shown as the space between (1) two surfaces, (2) surfaces and fault planes, or (3) surfaces and model extents. EV software follows basic geologic rules to define depositional, channel-fill, or unconformable contacts and surfaces. Surfaces can be modified by any or all of the following: adding data points to a surface, altering gridding parameters or detail, and using smoothing algorithms in any or all of the $\mathrm{x}, \mathrm{y}$, and $\mathrm{z}$ dimensions. This allows considerable discretion to define or refine a surface. Details of the algorithms and how data points are used by the software are beyond the scope of this report but are available from Dynamic Graphics, Inc., at URL http: //www.dgi.com.

Modeled faults have lengths greater than $4 \mathrm{~km}(2.5 \mathrm{mi})$ and inferred or known offsets greater than $20 \mathrm{~m}(65 \mathrm{ft})$. Splay faults or small isolated faults were not included in the model. Dips of faults were assigned from surface exposures where possible, otherwise they were assigned typical values based on 
data from regional surveys within the Española and adjacent basins (Minor and Hudson, 2006). For modeling, defining faults as through-going versus truncated was determined by geometric relations observed at the surface, as well as geologic interpretation (figs. 5 and 6). Due to modeling constraints, some faults or fault systems composed of multiple segments with common dip and strike were modeled as a single fault, such as the San Isidro Crossing fault. Elliptical boundaries for faults were generated to constrain their vertical and horizontal extents, in keeping with rock mechanical models of fault growth (Nichol and others, 1996). The elliptical boundaries were further modified to constrain faults that do not cut the Ancha Formation. Their vertical boundaries were defined by the top of the underlying Tesuque Formation and reflect the period of erosion and cessation of faulting between deposition of the Tesuque and Ancha Formations.

Model construction started with a few faults and geologic surfaces to test interpretations and modeling techniques, and to allow the authors input to refine the modeling process. After each model iteration was accepted, more data were added, interpretations of stratigraphy and structure were refined, and the model evolved and increased in complexity. The resultant model reflects interpretations through consensus of the authors as constrained by the data during the process. All data and interpretations were evaluated for consistency, quality, and accuracy using two- and three-dimensional visual analysis of all data sets. This process of model building resulted in a better understanding of the geology and structure within the study area and increased model accuracy.

\section{Methodology}

The fault framework was modeled first and includes 27 faults and fault segments. Normal faults with steep dips were determined on the basis of field mapping or inferred from recognized extensional strain in a rift basin (Minor and Hudson, 2006). Modeled faults were added sequentially as follows: (1) faults that cross the model, (2) faults that truncated other faults, and (3) faults to help show the basin form and the horst/graben relations. Some faults indicated only in the geophysical data did not have enough information to define vertical displacement. In these cases minimal fault displacements within the error tolerances of the data sets were added, typically $100 \mathrm{ft}$. Some faults had their inferred displacements at depth further constrained to be consistent with other known faulted surfaces

Where data or detail were missing for hydrogeologic surfaces, data points were extrapolated to be consistent with known data points based on local thickness of modeled units, or known fault displacements. For example, if the only local data control for a surface was the contact on the geologic map, we used that $\mathrm{x}, \mathrm{y}$, and $\mathrm{z}$ value, and calculated local overlying and/or underlying z-surface-elevation values based on local thickness. Some of the thickness and surface variations shown in the model may reflect additional small faulting or inherent uncertainties of defined picks from the data and are reasonable interpretations based on the objective criteria in surface maps, lithologic descriptions, and geophysical interpretations.

Topography-surface detail was designed to model topographic and structural detail and to balance this with what can be interactively displayed on a typical Intel ${ }^{\mathrm{TM}}$ single-processor computer system running Windows $\mathrm{XP}^{\mathrm{TM}}$ as defined in the readme1.txt file on this DVD-ROM.

The top of Precambrian basement is the lowermost modeled unit and was used to propagate and validate deep fault structures defined and shown on geologic and geophysical maps. This was necessary because the modeling technique builds the geologic layers from the bottom up, and fault displacement propagates vertically until other data are available, or some model extent or boundary is reached. Mapped displacements of many faults were less than the margin of error of the surfaces interpreted from geophysics. Thus structural displacements represented by geophysically defined grids were often adjusted to fit the surface geologic mapping more closely.

The intrusive unit was built as a series of stacked concentric polygons. Individual branches or spurs were integrated into a central column as interpreted from the subsurface geophysics. These stacked polygons were compiled as a 3-D object and scaled to the model. The intrusive unit was then added to the model as an unconformity.

The Cerros del Rio volcanic field caps the Tesuque surfaces from the eastern edge of the field westward. The Tesuque surfaces under the field was modeled to dip slightly westward. A wedge of the Cerros del Rio volume was built on top of this surface using the highest topographic points from the DEM and field observations and then projecting and thinning the unit eastward onto interpreted pre-erosion surfaces of the Tesuque Formations. The Cerros del Rio cap, along with the Tesuque unit was artificially eroded with the DEM to produce the cliff faces seen in the model.

\section{Conclusions}

The three-dimensional model of the southern Española Basin presents an internally consistent interpretation of surfaces and associated volumes developed from geologic and geophysical data. Major structures and rock-unit outcrop patterns of this model are mostly consistent with the geologic maps presented by Read and others (2005) and Koning and Read (2010), and subsurface interpretations of Grauch and others (2009). Differences seen in the model reflect interpretation of fault relations at depth, fault relations to lithologic contacts, or the surface DEM simplification or consolidation to fit the scale of the model and meet the practical limitations of the software. 
The model shows the overall geometry of the basin; a faulted north-plunging syncline with the southern shallow shelf of the Santa Fe embayment, and the transition to a deeper west-tilted half graben to the north across the curvilinear Rancho Viejo hinge zone. The model illustrates the distribution and thickness of the rift-filling Tesuque and Ancha Formations of the Santa Fe Group, both important basin aquifers. Modeled are twenty-seven faults that impact the basin form and potentially affect hydrologic flow. Faults offset the Tesuque Formation and older units and include the Agua Fria and Barrancos fault systems in the north-central part of the model, and the Tijeras-Cañoncito fault in the south. The model provides a geologic framework to develop regional groundwater models and allows exploration of possible groundwater pathways along or across fault boundaries and through tilted and fractured structures that resulted from faulting in this part of the Española Basin.

\section{References Cited}

Abbott, J.C., Cather, S.M., and Goodwin, L.B., 1995, Paleogene synorogenic sedimentation in the Galisteo Basin related to the Tijeras-Cañoncito fault system: New Mexico Geological Society Guidebook 46, p. 271-278.

Abbott, J.C., Goodwin, L.B., Kelley, S.A., Maynard, S.R., and McIntosh, W.C., 2004, The anatomy of a long-lived fault system-structural and thermochronologic evidence for Laramide to Quaternary activity on the Tijeras fault, New Mexico, in Cather, S.M., McIntosh, W.C., and Kelley, S.A., eds., Tectonics, geochronology, and volcanism in the Southern Rocky Mountains and Rio Grande rift: New Mexico Bureau of Geology and Mineral Resources Bulletin 160, p. 113-138.

Aldrich, M.J., Jr., 1986, Tectonics of the Jemez lineament in the Jemez Mountains and Rio Grande rift: Journal of Geophysical Research, v. 91, no. B2, p. 1753-1762.

Borchert, C.I., Skotnicki, S., and Read, A.S., 2003, Preliminary geologic map of the Tesuque 7.5-minute quadrangle, Santa Fe County, New Mexico: New Mexico Bureau of Geology and Mineral Resources Open-File Geologic Map OF-GM 47, scale 1:24,000.

Caine, J.S., and Minor, S.A., 2009, Structural and geochemical characteristics of faulted sediments and inferences on the role of water in deformation, Rio Grande rift, New Mexico: Geological Society of America Bulletin, v. 121, nos. 9-10, p. 1325-1340, DOI: 10.1130/B26164.1.

Cather, S.M., 1992, Suggested revisions to the Tertiary tectonic history of north-central New Mexico: New Mexico Geological Society Guidebook 43, p. 109-122.
Cather, S.M., 2004, Laramide orogeny in central and northern New Mexico and southern Colorado, in Mack, G.H., and Giles, K.A., eds., The geology of New Mexico: New Mexico Geological Society Special Publication 11, p. 203-248.

Cather, S.M., Timmons, J.M., and Karlstrom, K.E., 2005, Regional tectonic inferences for the $1.4 \mathrm{Ga}-$ Holocene lateral slip history of the Picuris-Pecos and related faults, northern New Mexico, in Lucas, S.G., Zeigler, K.E., Lueth, V.W., and Owen, D.E., eds., Geology of the Chama Basin: New Mexico Geological Society Guidebook, 56th Field Conference, p. 93-107.

Cavazza, William, 1986, Miocene sediment dispersal in the central Española Basin, Rio Grande rift, New Mexico, USA: Sedimentary Geology, v. 51, p. 119-135.

Chapin, C.E., and Cather, S.M., 1994, Tectonic setting of the axial basins of the northern and central Rio Grande rift, in Keller, G.R., and Cather, S.M., eds., Basins of the Rio Grande rift—Structure, stratigraphy, and tectonic setting: Boulder, Colo., Geological Society of America Special Paper 291, p. 5-25.

Connell, S.D., 2006, Preliminary geologic map of the Albuquerque-Rio Rancho metropolitan area and vicinity, Bernalillo and Sandoval Counties, New Mexico: New Mexico Bureau of Geology and Mineral Resources Open-File Report 496, 2 pls., scale 1:50,000.

Connell, S.D., Koning, D.J., and Cather, S.M., 1999, Revisions to the stratigraphic nomenclature of the Santa Fe Group, northwestern Albuquerque Basin, New Mexico, in Pazzaglia, F.J., and Lucas, S.G., eds., Albuquerque geology: New Mexico Geological Society Guidebook, 50th Annual Field Conference, p. 337-353.

Dethier, D.P., and Sawyer, D.A., 2006, Stratigraphy of upper Cenozoic fluvial deposits of the La Bajada constriction area, New Mexico, in Minor, S.A., ed., The Cerrillos uplift, the La Bajada constriction, and hydrogeologic framework of the Santo Domingo Basin, Rio Grande rift, New Mexico: U.S. Geological Survey Professional Paper 1720-B, p. 27-40.

Erskine, D.W., and Smith, G.A., 1993, Compositional characterization of volcanic products from a primarily sedimentary record: The Oligocene Espinaso Formation, north-central New Mexico: Geological Society of America Bulletin, v. 105, p. 1214-1222. 
Faulds, J.E., and Varga, R.J., 1998, The role of accommodation zones and transfer zones in the regional segmentation of extended terranes, in Faulds, J.E., and Stewart, J.H., eds., Accommodation zones and transfer zones: the regional segmentation of the Basin and Range Province: Boulder, Colo., Geological Society of America Special Paper 323, p. 1-45.

Finch, S.T., 2008, Hydrogeologic characteristics of the Tertiary-age Galisteo Formation, Santa Fe County, New Mexico, in Borchert, C.I., ed., Geologic and hydrologic framework of the Española Basin-Proceedings of the 6th Annual Española Basin workshop, March 6, 2007 [abs.]: New Mexico Bureau of Geology and Mineral Resources Open-File Report 508, p. 8.

Gardner, J.N., and Goff, Frazer, 1984, Potassium-argon dates from the Jemez volcanic field: Implications for tectonic activity in the north-central Rio Grande rift, in Baldridge, W.S., Dickerson, P.W., and Zidek, Jiri, eds., Rio Grande rift: northern New Mexico: New Mexico Geological Society Guidebook, 35th Field Conference, p. 75-81.

Giles, D.L., 1995, Cerrillos mining district, in Bauer, P.W., Maynard, S.R., Smith, G.A., Giles, D.L., Lucas, S.G., Barker, J.M., Smith, E.W., and Kottlowski, F.E., eds., Thirdday road log, from Santa Fe to the Cerrillos Hills, Cerrillos and the Ortiz Mountains: New Mexico Geological Society Guidebook, 46th Field Conference, Geology of the Santa Fe Region, p. 61-62.

Grauch, V.J.S., Sawyer, D.A., Hudson, M.R., Minor, S.A., and Thompson, R.A., 2006, Gravity and aeromagnetic studies in the Santo Domingo Basin area, in Minor, S.A., ed., The Cerrillos uplift, the La Bajada constriction, and hydrogeologic framework of the Santo Domingo Basin, Rio Grande rift, New Mexico: U. S. Geological Survey Professional Paper 1720-D, p. 63-86.

Grauch, V.J.S., and Hudson, M.R., 2007, Guides to understanding the aeromagnetic expression of faults in sedimentary basins: Lessons learned from the central Rio Grande rift, New Mexico: Geosphere, v. 3, no. 6, p. 596-623, DOI: 10.1130/GES00128.1.

Grauch, V.J.S., Phillips, J.D., Koning, D.J., Johnson, P.S., and Bankey, Viki, 2009, Geophysical interpretations of the southern Española Basin, New Mexico, that contribute to understanding its hydrogeologic framework: U.S. Geological Survey Professional Paper 1761, 88 p.

Johnson, P.S., Koning, D.J., and Felix, B., 2008, Elevation contour map of the base of the Ancha Formation, southern Española Basin, New Mexico: New Mexico Bureau of Geology and Mineral Resources Open-File Report 519, CD-ROM.
Karlstrom, K.E., Cather, S.M., Kelley, S.A., Heizler, M.T., Pazzaglia, F.J., and Roy, M., 1999, Sandia Mountains and Rio Grande rift: ancestry of structures and history of deformation, in Pazzaglia, F.J., and Lucas, S.G., eds., Albuquerque geology: New Mexico Geological Society Guidebook, 50th Annual Field Conference, p. 155-165.

Karlstrom, K.E., and Humphreys, E.D., 1998, Persistent influence of Proterozoic accretionary boundaries in the tectonic evolution of southwestern North America-Interaction of cratonic grain and mantle modification events: Rocky Mountain Geology, v. 33, no. 2, p. 161-179.

Kautz, P.F., Ingersoll, R.V., Baldridge, W.S., Damon, P.E., and Shafiqullah, M., 1981, Geology of the Espinaso Formation (Oligocene), north-central New Mexico-Summary: Geological Society of America Bulletin, Part I, v. 92, p. 980-983.

Kelley, V.C., 1979, Tectonics, middle Rio Grande rift, New Mexico, in Riecker, R.E., ed., Rio Grande rift-Tectonics and magmatism: Washington, D.C., American Geophysical Union, p. 57-70.

Kelley, V.C., 1982, The right-relayed Rio Grande rift, Taos to Hatch, New Mexico, in Grambling, J. A., and Wells, S.G., eds., Albuquerque country II: New Mexico Geological Society Guidebook 33, p. 147-151.

Kelson, K.I., Bauer, P.W., Unruh, J.R., and Bott, J.D.J., 2004, Late Quaternary characteristics of the northern Embudo fault, Taos County, New Mexico, in Brister, B.S., Bauer, P.W., Read, A.S., and Lueth, V.W., eds., Geology of the Taos region: New Mexico Geological Society Guidebook, 55th Annual Field Conference, p. 147-157.

Koning, D.J., 2005 (orig. publ. 2002), Preliminary geologic map of the Española 7.5-minute quadrangle, Rio Arriba and Santa Fe Counties, New Mexico: New Mexico Bureau of Geology and Mineral Resources Open-File Geologic Map OF-GM-54, scale 1:24,000.

Koning, D.J., and Aby, S.B., 2005, Proposed members of the Chamita Formation, north-central New Mexico: New Mexico Geological Society, 56th Field Conference Guidebook, Geology of the Chama Basin, p. 258-278.

Koning, D.J., Ferguson, J.F., Jackson-Paul, Patricia, and Baldridge, W.S., 2004, Geologic structure of the Velarde graben and the southern Embudo fault system, north-central New Mexico, in Brister, B.S., Bauer, P.W., Read, A.S., and Lueth, V.W., eds., Geology of the Taos region: New Mexico Geological Society Guidebook, 55th Annual Field Conference, p. 158-171. 
Koning, D.J., and Johnson, P.S., 2005, Textural and thickness variability of the Ancha Formation in the Santa Fe embayment, Rio Grande rift, north-central New Mexico, in McKinney, K.C., ed., Geologic and hydrogeologic framework of the Española Basin - Proceedings of the 4th annual Española Basin workshop, Santa Fe, New Mexico, March 1-3, 2005 [abs.]: U.S. Geological Survey Open-File Report 2005-1130, p. 22.

Koning, D.J., and Johnson, P.S., 2006, Locations and textural contrasts of Tesuque Formation lithostratigraphic units in the southern Española Basin, New Mexico, and hydrogeologic implications, in McKinney, K.C., ed., Geologic and hydrogeologic framework of the Española BasinProceedings of the 5th annual Española Basin workshop, Santa Fe, New Mexico, March 7-8, 2006 [abs.]: U.S. Geological Survey Open-File Report 2006-1134, p. 24.

Koning, D.J., and Maldonado, F., 2003, Geologic map of the Horcado Ranch quadrangle, Santa Fe County, New Mexico: New Mexico Bureau of Geology and Mineral Resources Open-File Geologic Map OF-GM 44, scale 1:24,000.

Koning, D.J., Nyman, M., Horning, R., Eppes, M., and Rogers, S., 2005 (orig. publ. 2002), Preliminary geologic map of the Cundiyo 7.5-minute quadrangle, Santa Fe County, New Mexico: New Mexico Bureau of Geology and Mineral Resources Open-File Geologic Map OF-GM-56, scale 1:24,000.

Koning, D.J., Pazzaglia, F.J., and McIntosh, W.C., 2002, Redefinition of the Ancha Formation and Pliocene-Pleistocene deposition in the Santa Fe embayment, north-central New Mexico: New Mexico Geology, v. 24, no. 3, p. 75-87.

Koning, D.J., and Read, A.S., 2010, Geologic map of the southern Española basin: New Mexico Bureau of Geology and Mineral Resources Open-file Report 531, ver. 1.0, scale $1: 48,000$.

Koning, D.J, Smith, G.A., and Read, A.S., 2008, Cenozoic stratigraphy in the Santa Fe embayment and northwards to the Buckman well field, Española Basin, New Mexico, in Borchert, C.I., ed., Geologic and hydrogeologic framework of the Española Basin-Proceedings of the 6th annual Española Basin workshop, Santa Fe, New Mexico, March 6, 2007 [abs.]: New Mexico Bureau of Geology and Mineral Resources Open-File Report 508, p. 2.

Lewis, A.C., and West, F., 1995, Conceptual hydrologic systems for Santa Fe County: New Mexico Geological Society Guidebook, v. 46, p. 299-306.
Lisenbee, A.L., Woodward, L.A., and Connolly, J.R., 1979, Tijeras-Cañoncito fault system-A major zone of recurrent movement in north-central New Mexico: New Mexico Geological Society Guidebook, v. 30, p. 89-99.

Longworth, J.W., Valdez, J.M., Magnuson, M.L., Albury, E.S., and Keller, J., 2008, New Mexico water use by categories: New Mexico Office of the State Engineer Technical Report $52,122 \mathrm{p}$.

Lucas, S.G., Cather, S.M., Abbott, J.C., and Williamson, T.E., 1997, Stratigraphy and tectonic implications of Paleogene strata in the Laramide Galisteo Basin, north-central New Mexico: New Mexico Geology, v. 19, no. 4, p. 89-95.

May, S.J., and Russell, L.R., 1994, Thickness of the syn-rift Santa Fe Group in the Albuquerque Basin and its relation to structural style, in Keller, G.R., and Cather, S.M., eds., Basins of the Rio Grande rift — Structure, stratigraphy, and tectonic setting: Boulder, Colo., Geological Society of America Special Paper 291, p. 113-124.

Maynard, S.R., Lisenbee, A.L., and Rogers, John, 2002, Geology of the Picture Rock 7.5-minute quadrangle, Santa Fe County, New Mexico: New Mexico Bureau of Geology and Mineral Resources Open-File Geologic Map OF-GM-51, scale 1:24,000.

Minor, S.A., ed., 2006, The Cerrillos uplift, the La Bajada constriction, and hydrogeologic framework of the Santo Domingo Basin, Rio Grande rift, New Mexico: U. S. Geological Survey Professional Paper 1720, 189 p.

Minor, S.A., and Hudson, M.R., 2006, Regional survey of structural properties and cementation patterns of fault zones in the northern Albuquerque Basin, New Mexico-Implications for groundwater flow: U.S. Geological Survey Professional Paper 1719, $28 \mathrm{p}$.

Myer, Caroline, and Smith, G.A., 2006, Stratigraphic analysis of the Yates \#2 La Mesa well and implications for southern Española Basin tectonic history: New Mexico Geology, v. 28 , no. 3 , p. $75-83$.

New Mexico Bureau of Geology and Mineral Resources, 2003, Geologic map of New Mexico: New Mexico Bureau of Geology and Mineral Resources, scale 1:500,000.

Nichol, A., Watterson, J., Walsh, J.J., and Childs, C., 1996, The shapes, major axis orientation and displacement patterns of fault surfaces: Journal of Structural Geology, v. 18, p. 235-248. 
Read, A.S., Koning, D.J., and Johnson, P.S., 2005 (orig. publ. 2004), Generalized geologic map of the southern Española Basin, Santa Fe County, New Mexico: New Mexico Bureau of Geology and Mineral Resources Open-File Report 481, scale 1:50,000.

Read, A.S., Koning, D.J., Smith, G.A., Ralser, S., Rogers, J., and Bauer, P.W., 2003 (orig. publ. 2000), Preliminary geologic map of the Santa Fe 7.5-minute quadrangle: New Mexico Bureau of Geology and Mineral Resources OpenFile Geologic Map OF-GM-32, scale 1:24,000.

Read, A.S., Rogers, J.B., Ralser, S., Ilg, B.R., and Kelley, S., 2004, (orig. publ. 1999), Preliminary geologic map of the Seton Village 7.5-minute quadrangle, Santa Fe County, New Mexico: New Mexico Bureau of Geology and Mineral Resources Open-File Geologic Map OF-GM-23, scale $1: 24,000$.

Rodriguez, B.D., Deszcz-Pan, M., and Sawyer, D.A., 2006, Electromagnetic studies and subsurface mapping of electrical resistivity in the La Bajada constriction area, New Mexico, in Minor, S.A., ed., The Cerrillos uplift, the La Bajada constriction, and hydrogeologic framework of the Santo Domingo Basin, Rio Grande rift, New Mexico: U.S. Geological Survey Professional Paper 1720-F, p. 118-162.

Rosendahl, B.R., 1987, Architecture of continental rifts with special reference to east Africa: Annual Review of Earth and Planetary Sciences, v. 15, p. 445-503.

Russell, L.R., and Snelson, S., 1994, Structure and tectonics of the Albuquerque Basin segment of the Rio Grande riftInsights from reflection seismic data, in Keller, G.R., and Cather, S.M., eds., Basins of the Rio Grande rift-Structure, stratigraphy, and tectonic setting: Boulder, Colo., Geological Society of America Special Paper 291, p. 83-112.

Sawyer, D.A., and Minor, S.A., 2006a, Geologic setting of the La Bajada constriction and Cochiti Pueblo area, New Mexico, in Minor, S.A., ed., The Cerrillos uplift, the La Bajada constriction, and hydrogeologic framework of the Santo Domingo Basin, Rio Grande rift, New Mexico: U.S. Geological Survey Professional Paper 1720-A, p. 1-23.

Sawyer, D.A., and Minor, S.A., 2006b, Hydrogeologic framework of the La Bajada constriction area, New MexicoIntegration of subsurface and surface geology, in Minor, S.A., ed., The Cerrillos uplift, the La Bajada constriction, and hydrogeologic framework of the Santo Domingo Basin, Rio Grande rift, New Mexico: U.S. Geological Survey Professional Paper 1720-G, p. 167-189, scale: 1:24,000.
Sawyer, D.A., Mullins, K.F., Dohrenwend, J., and Isbrecht, J.A., 2004, Processed Landsat 7 satellite imagery of the Española Basin region, New Mexico: U.S. Geological Survey Open-File Report 2004-1040 A, CD-ROM.

Sawyer, D.A., Shroba, R.R., Minor, S.A., Thompson, R.A., and Blossom, J.C., 2002, Geologic map of the Tetilla Peak quadrangle, Sante Fe and Sandoval Counties, New Mexico: U.S. Geological Survey Miscellaneous Field Studies Map $\underline{\mathrm{MF}-2352 .}$

Smith, G.A., McIntosh, William, and Kuhle, A.J., 2001, Sedimentologic and geomorphic evidence for seesaw subsidence of the Santo Domingo accommodation-zone basin, Rio Grande rift, New Mexico: Geological Society of America Bulletin, v. 113, p. 561-574.

Smith, G.A., Larsen, D., Harlan, S.S., McIntosh, W.C., Erskine, D.W., and Taylor, S., 1991, A tale of two volcaniclastic aprons - Field guide to the sedimentology and physical volcanology of the Oligocene Espinaso Formation and Miocene Peralta Tuff, north-central New Mexico, in Julian, Betsy, and Zidek, Jiri, eds., Field guide to geologic excursions in New Mexico and adjacent areas of Texas and Colorado: New Mexico Bureau of Mines and Mineral Resources Bulletin 137, p. 87-103.

Smith, R.L., Bailey, R.A., and Ross, C.S., 1970, Geologic map of the Jemez Mountains, New Mexico: U.S. Geological Survey Miscellaneous Investigations Map I-571, scale $1: 125,000$.

Smith, R.L., and Bailey, R.A., 1968, Resurgent cauldrons, in Coats, R.R., Hay, R.L., and Anderson, C.A., eds., Studies in volcanology: Geological Society of America Memoir 116, p. 613-662.

Spiegel, Zane, and Baldwin, Brewster, 1963, Geology and water resources of the Santa Fe area, New Mexico, with contributions by F.E. Kottlowski and E.L. Barrows and $a$ section on geophysics by H.A. Winkler: U.S. Geological Survey Water-Supply Paper 1525, 258 p.

Thompson, R.A., Sawyer, D.A., Hudson, M.R., Grauch, V.J.S., and McIntosh, W.C., 2006, Cenozoic volcanism of the La Bajada constriction region, in Minor, S.A., ed., The Cerrillos uplift, the La Bajada constriction, and hydrogeologic framework of the Santo Domingo Basin, Rio Grande rift, New Mexico: U.S. Geological Survey Professional Paper 1720-C, p. 41-60.

Williams, P.L., and Cole, J.C., 2007, Geologic map of the Albuquerque 30' x 60' quadrangle, north-central New Mexico: U.S. Geological Survey Scientific Investigations Map 2946, 31 p., scale: 1:100,000. 


\section{DVD-ROM Contents}

In addition to this discussion, this publication contains a complete faulted 3-D surface and volume model of the study area. The model may be explored and .jpg or tiff images of user-defined views may be saved. Both a basic "getting started" help file and detailed help files are pro-vided as aids to understanding the included 3-D viewer. The included viewer is for Windows. The USGS has licensed from Dynamic Graphics, Inc., the rights to provide an encrypted model and the viewers to use the interpreted model. The license allows the USGS the service and rights to provide unlimited distribution. We designed this product to function from the DVD-ROM media but recommend the necessary files be copied to a local hard drive for better performance. No additional installation programs are needed to view the model and data sets using the 3 -D viewer. Error messages may occur referencing the Microsoft $\mathrm{C}++$ libraries when starting the software; selecting "OK" several times will start the software. There is no damage done to your system because nothing is installed. The folder "bug_fix" includes a possible fix for this problem and is provided as a courtesy by Dynamic Graphics. More information about the viewing software and EarthVision ${ }^{\mathrm{TM}}$ may be obtained from Dynamic Graphics, Inc., at http://www.dgi.com/. 
Publishing support provided by:

Denver Publishing Service Center

For more information concerning this publication, contact:

Center Director, USGS Geology and Environmental Change Science Center Box 25046, Mail Stop 980

Denver, CO 80225

(303) 236-5344

Or visit the Geology and Environmental Change Science Center Web site at: http://esp.cr.usgs.gov/ 
